OPEN ACCESS

Approved by:

Frontiers Editorial Office, Frontiers Media SA, Switzerland

*Correspondence:

Frontiers Production Office production.office@frontiersin.org

Specialty section: This article was submitted to Public Mental Health, a section of the journal

Frontiers in Psychiatry

Received: 14 January 2021

Accepted: 15 January 2021

Published: 08 February 2021

Citation:

Frontiers Production Office (2021)

Erratum: COVID-19 Suicide

Survivors - A Hidden Grieving Population.

Front. Psychiatry 12:653544. doi: 10.3389/fpsyt.2021.653544

\section{Erratum: COVID-19 Suicide Survivors-A Hidden Grieving Population}

\author{
Frontiers Production Office* \\ Frontiers Media SA, Lausanne, Switzerland
}

Keywords: complicated grief, suicide, suicide survivors, COVID-19, intervention, prevention

\section{An Erratum on}

\section{COVID-19 Suicide Survivors-A Hidden Grieving Population}

by Pinto, S., Soares, J., Silva, A., Curral, R., and Coelho, R. (2020). Front. Psychiatry 11:626807. doi: $10.3389 /$ fpsyt.2020.626807

Due to a production error, there was an error in affiliation for authors Sara Pinto, Alzira Silva, Rosário Curral, and Rui Coelho. Instead of "Psychiatry Service, Centro Hospitalar Universitário São João, Oporto, Portugal," it should be "Psychology Service, Centro Hospitalar Universitário São João, Oporto, Portugal." Only author Joana Soares is affiliated to "Psychiatry Service, Centro Hospitalar Universitário São João, Oporto, Portugal.” The publisher apologizes for this mistake.

The original article has been updated.

Copyright $(2021$ Frontiers Production Office. This is an open-access article distributed under the terms of the Creative Commons Attribution License (CC BY). The use, distribution or reproduction in other forums is permitted, provided the original author(s) and the copyright owner(s) are credited and that the original publication in this journal is cited, in accordance with accepted academic practice. No use, distribution or reproduction is permitted which does not comply with these terms. 